\title{
Cross-Cultural Study in Local- Wisdom for Creative Food Package Development in Secondary School
}

\author{
Sineenart Laedpriwan ${ }^{1}$; Wongduean Nuntatong2; Komnate \\ Ponsanthia ${ }^{3}$; Waristha Iam-In'; Bunkant Silpanurak ${ }^{5}$; \\ Pattamaporn Thunmarong; ${ }^{6}$ Paweena Chimklang ${ }^{7}$ \\ Srinakharinwirot University and Ministry of Education ${ }^{1}$; Maejadee Withayakom School, \\ Chiengrai ${ }^{2,6}$; Nikompimaisuksa School, Nakornrachasrima ${ }^{3,7}$; Rachaboriganukrough, Rachaburee ${ }^{4}$; \\ Panagtungsuksa, Patalung ${ }^{5}$
}

\begin{abstract}
The purposes of this research were ๑) to study the wisdom of Thai food package by wrapping and packing technique from the local Thai and Japanese food experts. ๒) to develop the WisdomTransferring Model of food packaging $₫)$ To experiment the specific program of Wisdom-Transferring Model of food packaging in Secondary school: Mathayomsuksa 4th year. The experimental program was examined in Thailand locally separated into 4 parts $/ 4$ schools. The result of this research can be explained the transferring technique of Thai wrapping were similar in attitudes and beliefs. The subject should described the content of materials and processes which directly matched with the subject of professional practice and technology together with the social science/cultural and history integrated with English understanding language The researcher founded that the program of Thai Wisdom Transferring has contained to be 24 hours or $4=$ full day a continuing program. The control group of this research sample has increasing their creativity in wrapping and packaging up to $40.89 \%$ in attitude and belief and 55, 84\% the same as the meaning between languages.
\end{abstract}

Keywords: knowledge transmissible, wisdom, food-package development, packaging

\section{INTRODUCTION}

The method of the knowledge transferring messages could be described by effectiveness of social science and behavior in community. The tacit knowledge in each community from family to the childhood usually happened from environmental aspects and geographical situation. There are varieties of traditional food in various parts of each country which so called community's food and traditional cooking styles. In any of geographical situations, people can find material which is usually derived from nature on the other hand food process derived from wisdom in community. The previous generation of people have developed those community's food so many times until it could be measured by today behavior in each society (Torger Gillebo, 2010).

Therefore, we can find the similarity and differentiation in traditional food by distances. The processes of cooking between communities are slightly different in appearance. There are differences of materials and cultural process in food preservation technique. This situation causes cultural of food in community 
(Goffman. E, 1956). The development of food preservation in community has been developed from day to day until the particular food became signature in each particular area (Paul E, Bierly III, Eric H. Kressler, Edward W. Christensen, 2001). Then those procedures have been derived to the new generation by experimental activities for living (Bryant, De Walt, Courtney, \& Schwartz, 2003; Korthals, 2002). Moreover, the study of wisdom in food preservation could be integrated with the new technology to create the innovation of food products for creative economy in community (Michel Boko, Antoine Heideveld, Anne Elsen, 1997).

Wrapping technique is the most favorite ways of preservation program for traditional food in each area. The quality of food not only means by the ingredient and material but also the process of food wrapping technique. People knew how to preserve food in any of short and long term preservation. They have found how to pick up natural material such a huge piece of leaf to hold all the ingredient mixtures. (Flávio Meira Borém, Fabiana Carmanini Ribeiro, Luisa Pereira Figueiredo, Gerson Silva Giomo, Valquíria Aparecida Fortunato, Eder Pedroza Isquierdo, 2011). Therefore, traditional food usually separated from the long term of food preservation. The particular area has their own criteria of community's consumption (จุลทัศน์พยาฆรานนห์, 2543: 8). As a matter of fact, the ingredient of traditional food must effects on quality of food in each community. There are some basic physical aspects influence to the cultural food and learning process of traditional cooking styles which appeared on "Country Styles of Food" such as Japanese, Chinese, Italian or event Thai Traditional Styles (Torger Gillebo, 2010) (Goffman. E, 1956). Besides, the integration of preservation technique has been suitably developed for each area and certainly shown the particular style.

Moreover, the development of food will be extended day by day in each society (Paul E, Bierly III, Eric H. Kressler, Edward W. Christensen, 2001). People learning from generation to generation and develop process by telling stories, observation and also the experimental activities (Bryant, De Walt, Courtney, \& Schwartz, 2003; Korthals, 2002). In Japan, the country of best practice in packaging, people usually focus on product and packaging to locally create their own techniques in food wrapping from local wisdom. (Michel Boko, Antoine Heideveld, Anne Elsen, 1997), Finally, it became signature of traditional food in Japan.

The food creation technique in community usually start up by divided food into two separate categories: one is for fresh cooking, another is for preservation. Therefore, people must consume food for the whole year long (Flávio Meira Borém, Fabiana Carmanini Ribeiro, Luisa Pereira Figueiredo, Gerson Silva Giomo, Valquíria Aparecida Fortunato, Eder Pedroza Isquierdo, 2011). In the old day, people believed that leaves can be able to contain food by keeping in lower temperature and make sure that it wouldn't be spoiled for a while. The leaves would be provided by natural plant in each area (ชาติ ชายอนุ กูล, 2554).

Food packing techniques are developed from the integration of various cultures and technology in each area. The natural wrapping material would be similar in neighborhood but different from wrapping techniques and cooking styles. Some 
area cooks them by boiling, some streaming or frying or event being grill. The wrapping technique can provide signature in taste and smell due to the cooking process and wrapped material (Paula Hook, Joe E. Heimlich, 2009). The traditional food can create value added to the signature one. Thai foods are divided into four traditional parts: Northern, North-Eastern, Central and Southern parts of Thailand. They have their own traditional technique in wrapping and cook from local wisdom. (มยุรี จัยวัฒน์, วรรณวิบูลย์กาญจนกุญชร, นงนุ ชรั กสกุลไทย, พงษ์เทพวิไลพันธ์, 2550). People usually find local material for holding and wrapping. In the old day, people never searching material from nature, there are so many materials for ingredient and cooking process. Mostly, the ingredient comes from local herbs and plants. They have applied their own wisdom by proportion and scale exploratory. People knew how to do mixed and matched in terms of quality in tasting and smelling.

The learning process of wisdom technique for creativity is not exactly appeared in the curriculum. The Basic Educational School open-widely full fill the detail of each professional practice subject which is the subject for living such as understand how to cook and experience in house hold technique. Anyhow, there are particular principles living in each society, culture, tradition in locally living. People can create their own advantage from their local wisdom by produce the national creative-economy for the tourist business. The results of learning in basic education program are four criterias of student's characteristics: 1) the Thinking of Knowledge (TOK); 2) Extended Essay; 3)CAS: Creative Action Service; and 4) Global Education. The learning process has been developed from two types of activity which are learning by doing and copying the previous process. In addition, there are followed by four types of process: interesting, memorizing, physical, and motivation process (Bandura A, 1993: 117-148).

Researcher founded that the idea of value-added by creative economy would produce the national strength of local business, the best practices providing for the tourist business in Thailand. Moreover, the basic educational concepts for ASEAN normally allow the particular school to create their own learning process of local wisdom in each area. Student might be expert in local wisdom and sustainably create new product and packaging for their own community.

\section{MATERIALS AND METHODS}

The research has been designed by studying main local wisdom of food from four parts of Thailand. The mixed method by starting with the qualitative interview and observation techniques followed by focus group discussion of professional program in product and package through the wisdom and development from students. The purpose of this research are to:

- To study the local wisdom of food wrapping and packing of 4 parts: Northern, North-Eastern, Central and Southern part of Thailand.

- To develop the professional learning program of food wrapping and packing techniques from local wisdom. 
- To explore the professional learning program for student creativity of 4 areas in the particular school.

The research hypothesis can be explained by the higher score results of creativity from the experimental group of student after attending the professional program in attitude and knowledge of product and package by the significance measurement of 0.05 . The sample sizes are 4 parts of Thailand. The group of sample are following:

$\begin{array}{ll}\text { Northen Part } & \text { : MaejadeeWithayakom School, Chiengrai } \\ \text { North-Eastern Part } & \text { : Nikompimaisuksa School, Nakornrachasrima } \\ \text { Central Part } & \text { : Rachaboriganukrough School, Rachaburee } \\ \text { Southern Part } & \text { : Panangtungsuksa School, Patalung }\end{array}$

The research frame work can be explained by following diagram:

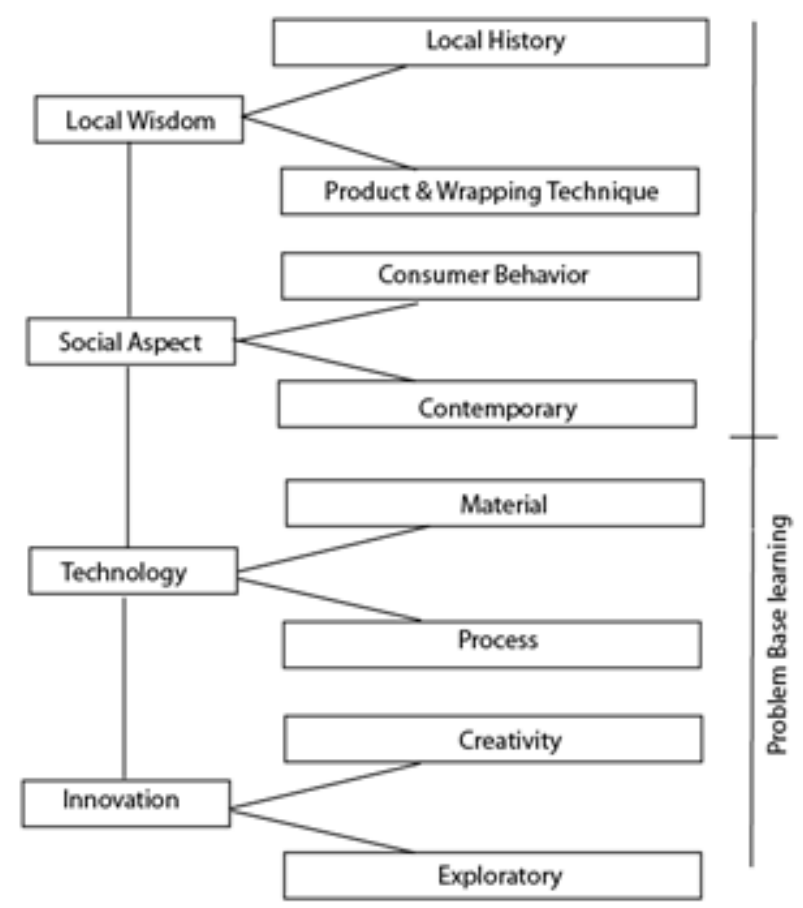

\section{RESULTS}

The research found the main signature of local wrapping food are Jin-Som in the Chiengrai, The Sugar-Palm Cake in North Eastern, The Nga-Salad Sweet in Central and the Sweet rice \& Kapoh leaf in Southern part. There are described by culture and traditional in each year. The cross cultural results are explained by material and process of wrapping technic and also the transferring of knowledge in community. There is main material which mostly use of wrapping that is banana leaf. Anyway, the wrapping technique are slightly different by experiences 
of local wisdom some of them are wrapped with bamboo stripe some took stick of coconut. Some of the wrapping technique is helping food to be cooked and ready to serve. Jin-Som has main ingredient from fresh meat. The others are sweet type of food which has to be enclosed the sweet ingredient by wrapping technique and protect them from streaming process suach as the Sugar-Palm Cake, NgaSalad and Sweet rice \&Kapoh leaf. The expert in community always transferring their wisdom knowledge by telling stories and legend of food and culture some are religious relevant but some are wrapping by tradition which means doing by following the old people, they believe that you might have better of live from doing such tradition every year.

The research focus on the professional program development for basic education school samples in secondary school from four parts of Thailand. The researcher founded that the program of Thai Wisdom-Transferring has contained to be 24 hours or 4-full day a continuing program. The control group of this research sample has increasing their creativity in wrapping and packaging up to $40.89 \%$ in attitude and belief and 55, 84\% the same as the meaning between languages.

\section{TABLES AND GRAPH}

\begin{tabular}{|c|c|c|}
\hline Jin-Som & Wrapping Material & Process \\
\hline & Banana & Mixing-N/A \\
\hline $\begin{array}{l}\text { Sugar- } \\
\text { Palm } \\
\text { Cake }\end{array}$ & Wrapping Material & Process \\
\hline & Banana & Mixing-Steaming \\
\hline $\begin{array}{l}\text { Nga- } \\
\text { Salad }\end{array}$ & Wrapping Material & Process \\
\hline $\operatorname{ls}^{3} x$ & Banana & Cooking-N/A \\
\hline $\begin{array}{c}\text { Sweet rice \& Kapoh } \\
\text { leaf }\end{array}$ & Wrapping Material & Process \\
\hline $2 \geq 1$ & Kapoh Leaf & Mixing - Boil \\
\hline
\end{tabular}

Table 1: The component of actual wrapping food between 4 parts of Thailand 


\begin{tabular}{|l|c|c|c|c|c|c|c|c|c|c|c|c|}
\hline \multicolumn{1}{|c|}{ Control Group } & \multicolumn{3}{|c|}{$\begin{array}{c}\text { Tools 1 } \\
\text { Knowledge }\end{array}$} & \multicolumn{3}{c|}{$\begin{array}{c}\text { Tools 2 } \\
\text { Practicum }\end{array}$} & \multicolumn{3}{c|}{$\begin{array}{c}\text { Tools 3 } \\
\text { Attitude }\end{array}$} & \multicolumn{3}{c|}{$\begin{array}{c}\text { Tools 4 } \\
\text { Creativity } \\
\text { Test }\end{array}$} \\
\hline \multicolumn{1}{|c|}{ N/NE/ C/S } & in & ax & ean & in & ax & ean & in & ax & ean & in & ax & ean \\
\hline $\begin{array}{l}\text { Maejadee with } \\
\text { ayakom School, Chiengrai }\end{array}$ & 0 & 6 & 8 & 6 & 8 & 2 & 5 & 00 & 1,5 & 0 & 8 & 9 \\
\hline $\begin{array}{l}\text { Nikompimaisuk } \\
\text { sa School, Nakornrachasrima }\end{array}$ & 5 & 6 & 0,5 & 3 & 6 & 4,5 & 0 & 8 & 4 & 8 & 0 & 4,5 \\
\hline $\begin{array}{l}\text { Rachaboriganukrough } \\
\text { School, Rachaburee }\end{array}$ & 4 & 9 & 2 & 2 & 7 & 4.5 & 7 & 6 & 1,5 & 0 & 5 & 7.5 \\
\hline \begin{tabular}{l} 
Panangtungsuksa School, Patalung \\
\hline
\end{tabular} & 5 & 9 & 7 & 3 & 5 & 0 & 0 & 7 & 8.5 & 2 & 7 & 4,5 \\
\hline
\end{tabular}

Table 2: The results of Tool 1-4

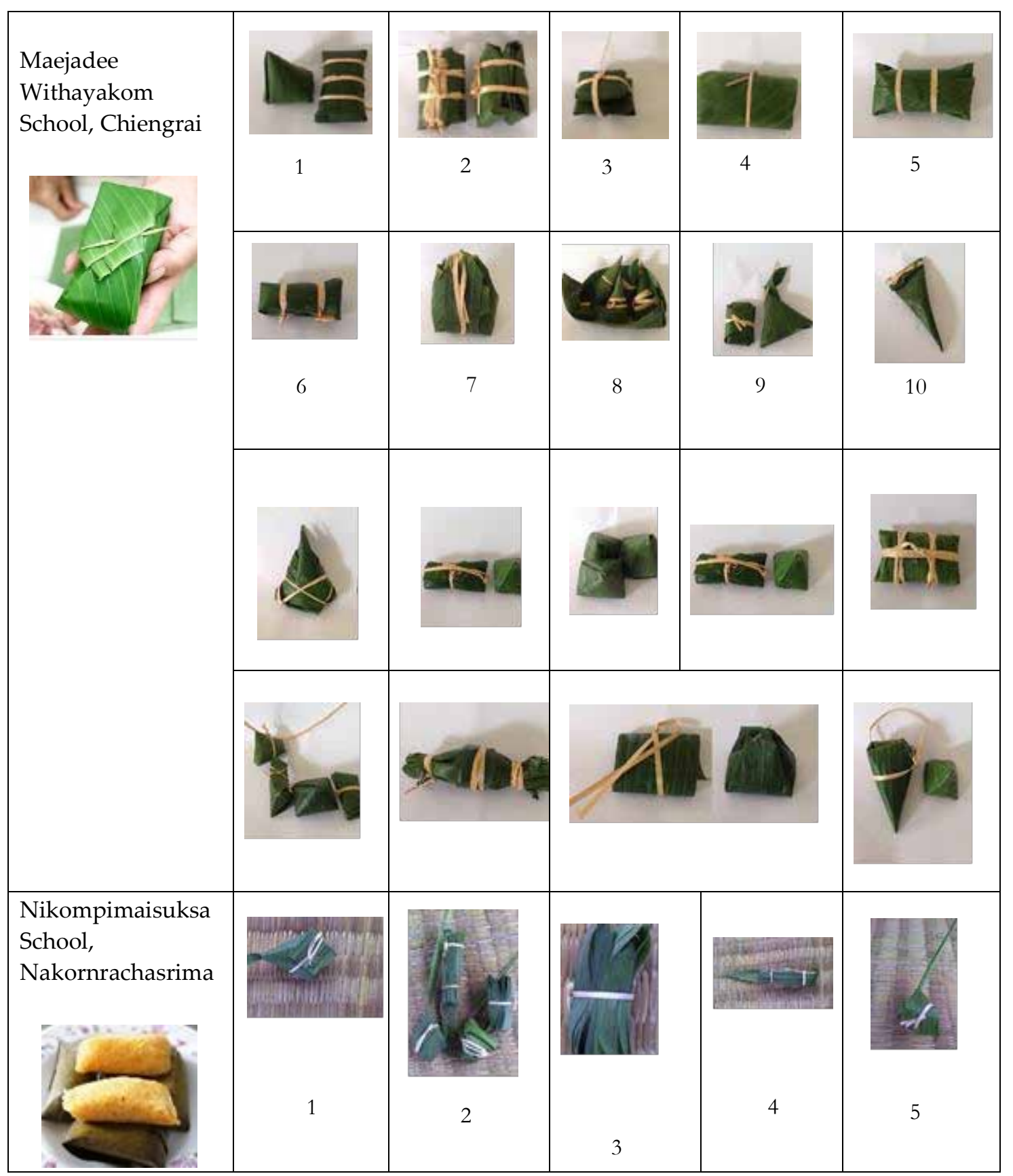




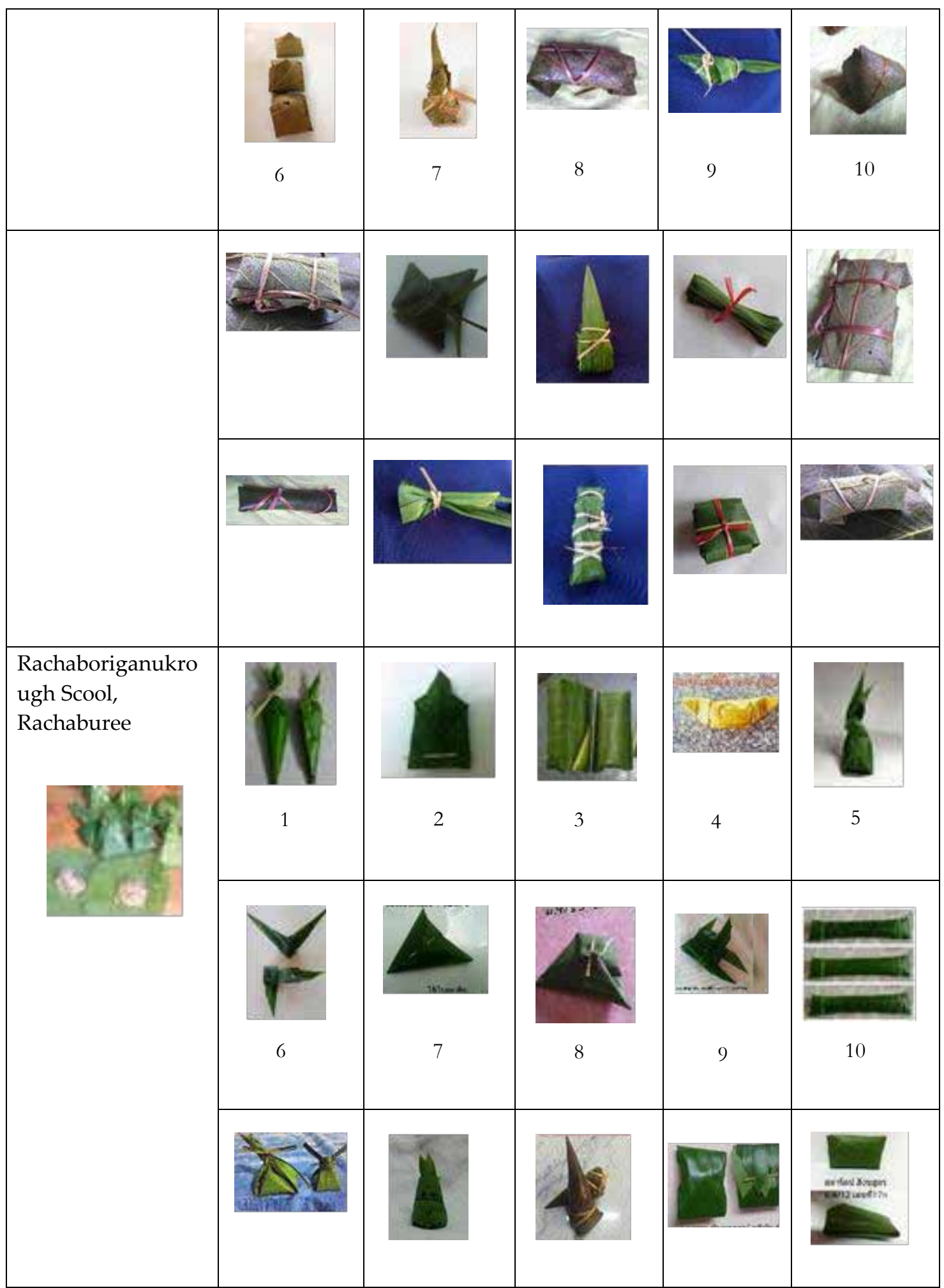




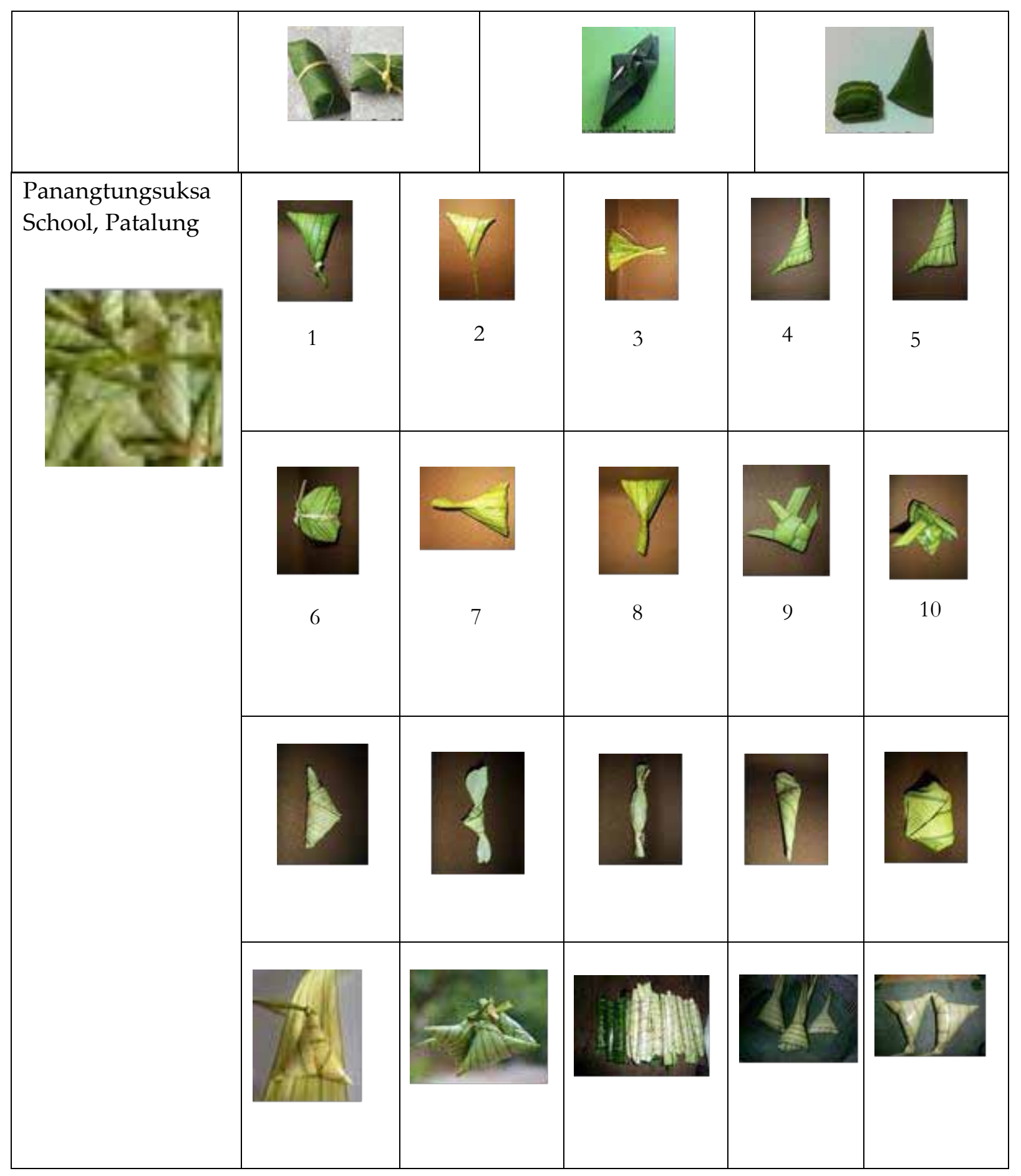

Table 3: The creative natural package applied from local wisdom

\section{DISCUSSION}

The wisdom of wrapping food in community has been developed in particular area focus on geographical aspects, the integration of culture and the knowledge in each society. The old generation people mostly transferred community's local wisdom by telling their cultural legend and demonstrated how to wrap and cook their traditional food for the special event and the annual festival. The tastes of the local food in all parts of the country are slightly different in detail of the 
selective material and how to prepare materials and cook each specific food in community. The banana leaves are mostly favorites for being wrapped because of their thickness and elasticity.

The creativity in food wrapping technique can create the innovation of product and development for national economy. The dignity in community will be inspiration for SME (Small and Medium Enterprise) to apply the new technology in social concern activities. The professional program for locally learning wisdom in school needed to be conducted in Secondary school curriculum to prepare student deeply understand their own local wisdom ready for being outstanding designer for each community.

The program must contain at least 4 days: 1) Historical knowledge; 2) Social Aspects in community; 3) Attitude \& Belief of wrapping food; 4) Human needs and behavior; 5) Creativity Development through practicum study.

Students learn how to develop their ideas under circumstances of local wisdom. The more they understand their own wisdom the more creativity are being touch and sustainably. It should be suggested that the school must intent to build up deeply understanding of local wisdom to the student in secondary school before attending in the university. The enrollment criteria should concern much about the experiences of local wisdom in the individual student by checking portfolio and certificates of professional program attending and workshop. So the undergraduate student in the university will be classified in 2 types: professional in downtown student and professional in specific local student. The university program of study will input trend and the new technology to push student to be great designer comparing with other countries.

\section{ACKNOWLEDGMENTS}

It is honor to acknowledge the Office of Basic Education and the Office of Higher Education for being coordinator of this research and provide spaces and classes in school to be expiratory concerned. The director of MaejadeeWithayakom SchoolChiengrai, Nikompimaisuksa School-Nakornrachasrima, Rachaboriganukrough School-Rachaburee, Panangtungsuksa School-Patalung. Also propose the acknowledgement to the Director of Behavior Science Research Institute, Srinakhariwirot University.

\section{REFERENCES (LITERATURE CITED)}

Maslow, Abraham. 1945. Motivation and Personality. New York, NY: Harper.

Osborn, Alex. 2007. Your Creative Power. Myer Press (March 15, 2007).

Anderson, A.B. 1983. Imagined Communities: Reflection on the Origin and Spread of Nationalism. London.

Cahill, Ardriana. 2550. Knowledge vs Wisdom. Controverscial.Com

Bandura, A. 1963. Imitation of Film-Mediated Aggressive Models. The Journal of Abnormal and Psychology, Vol. 66(1) Jan, 1963:3-11.

Bandura, A. 1986. Social Foundation of Thought and Action Cognitive Theory, Englewood Cliffs, NJ. 
Bandura, A. 1993. Perceived Self-Efficiency in Cognitive Development and Functioning, Educational Psychologist 28(2), 117-148.

Baron and Welsh. 1952. Creativity in Familial Bipolar Disorder, EL SEVIER, Journal of Psychiatric Research.

Russell, Berstrand. 1926. Theory of Knowledge. Encyclopedia Britanica.

Carol A., Bryant/Kathaleen M. Dewalt/Anita Courtney/Jeffery Schwartz. 2003. The Cultural Feast: An Introduction to Food and Society; Brooks/Cole Pub Co., Ltd.

Hewett, Casper. 2006. John Locke]s Theory of Knowledge. Durheim University.

MR,Catherine; Ishii K and Stevels A. 2002. Influencing design to improve product End-of-Life Stage, Research in Engineering Design 13: 83-93

Chen, J.S. 2000. Cross-cultural differences in travel information acquisition among Tourists from three Pacific-Rim countries, Journal of Hospitality and Tourism Research, 24: 239.

Collin Coulson, Thomas. 2000. Information Entrepreneur: Changing Requirements for Corporate and Individual Success. 3Com UK Ltd., Management Development Unit (May 5, 2000).

Crotts, J. \& Erdmann, R. 2000. Does national culture influence consumer's evaluation of Travel services? A test of Hofstede's model of cross-cultural differences, Managing Service Quality, 10 (6): 410-22.

Perkins, David. 1992. Smart School. Reed Business Information Inc.

Bier, Dennis. 2011. Public Health Challenges of Nutrition and Aging, USDA/ARS Children's Nutrition, Research Center.

Leonard, Dorothy and Swap, Walter. 2005. Deep Smart. United State, Boston: Harvard Business School Press.

Donthu, N. \&Yoo, B. 1998. Cultural influences on service quality expectations. Journal of Service Research, 1(2): 178-86.

Edward, B. Tyler. 1964. Nature and Art in Reneissance Literature. Better World Books.

Edward, B., Tylor. 1987. On a Method of Investigating the Development of Institutions, Applied to Laws of Marriage and Descent. Journal of Anthropology, Institute of Great Britain and Ireland 18 (1889), 245-72, Print.

Kants, Emmanuel. 1996. Critical of Pure Reason. Indianapolis Hackelt, XXVIII.

Furrer, O., Liu, B. \& Sudharshan, D. 2000. The relationship between culture and service quality perception: Basis for cross-cultural market segmentation and resource allocation, Journal of Service Research, 2(4): 355-71.

Flávio Meira Borém, Fabiana Carmanini Ribeiro, Luisa Pereira Figueiredo, Gerson

Silva Giomo, Valquíria Aparecida Fortunato, Eder Pedroza Isquierdo. 2011. Evaluation of the sensory and color quality of coffee beans stored in hermetic packaging. Journal of Stored Products Research, Copyright (C) 2011 Elsevier Ltd. All rights reserved.

Garai, L. 1996. Vygotskian implications: On the meaning and its brain Institute for Psychology, Hungarian Academy of Sciences (The Cultural-Historical Approach: Progress in Human Sciences and education; Moscow, 21-24 October, 1996).

E., Goffman. 1956. The Presentation of Self in Everyday Life. England: Penguin University Books.

J.P., Gilford. 1950. Creativity. American Psychologist, Volume 5, Issue 9, 444-454.

Grant, Thompson M. 1997. Toward A Knowledge base Theory of the Firm. Strategic Management Journal, Vol. 17(Winter Special Issue), 109-122 (1996).

Griswald. 1966. The Silent Slaughter, Youth Against War and Fascism (January 1, 1966)

H. Russell Bernard. 1940. Social Research Methods: Qualitative and Quantitative Approaches, Sage Publication Inc.

Hofstede, G. 1984. Culture's consequences: international differences in work related Values. (Abridged ed.). Beverly Hills, CA: Sage Publications. 
Hofstede, G. \& Hofstede, G.J. 2005. Cultures and organizations: Software of the mind. Revised and expanded 2nd ed. New York: McGraw-Hill.

Howard R. Moskowitz, Michele Reisner, John Benedict Lawlor, Rosires Deliza. 2009. Packaging Research in Food Product Design and Development, July 2009, WileyBlackwell.

Hundal M. 2000. Design for recycling and remanufacturing. Proceeding of International Design Conference-DESIGN 2000, Dubrovnik.

Jackson, M. 2001. Cultural Influences on Tourist Destination Choices of 21 Pacific Rim Nations. Paper presented at the CAUTHE national research conference, pp. 166176.

Jang, S. \& Cai, L. 2002. Travel motivations and destination choice: A study of British Outbound Market. Journal of Travel and Tourism Marketing, 13(3): 111-113.

Jonker, Jan, Pennink, Bartjan. 2009. 1st Edition. The Essence of Research Methodology, Springer.

Juran, Joseph. 2009. The Introduction to Total Quality Management JUSE, Quality Guru, Joseph Juran, Japanese Union of Scientists and Engineers, fitness for use, Juran's 10 steps to quality, corss-functional quality improvement.

Drachsler, Julius. 1920. Democracy and Assimilation. The Blending of Immigrant Heritages in America, Macmillan.

Kongprasertamorn, Kamolthip. 2007. Local Wisdom Environmental Protection and Community Development: Clam Farmers in Tumbon Bankhunsai, Petchaburi Province, Thailand, MANUSAYA, Journal of Humanity.

Ichikawa, Kazumi. 2010. Ume HokorobuKeshiyuu, Tanga/Haiku, 2010-05-19.

H., Kobayashi. 2005. Strategic evolution of eco-products: a Product Life Cycle Planning Methodology, Research in Engineering design 16: 1-16

Kroeber, A.L. \& Kluckhohn, C. 1952. Culture: A Critical Review of Concepts and Definitions. Harvard University: Peabody Museum of American Archeology and Ethnology.

Kuniyoshi SUGIMOTO1, Kazuaki TSUDA2, Katsumi NAGAHARA3, Takako KASHIWASE 4,

Hiroaki ETO5, Kazumi ICHIKAWA6, and Tetsu KAWABATA7. 2004. Performance Evaluation Method for Reinforced Concrete Buildings, 13th World Conference on Earthquake Engineering Vancouver, B.C., Canada.

Laszló Garaiand Margit Kocski. 1995. Another Crisis in the Psychology: A Possible Motive for the Vygotsky Boom. Budapest: Institute for Psychology of the Hungarian Academy of Sciences.

Lee CH, Chang SL, Wang KM, and Wen LC. 2000. Management of Scrap Computer Recycling in Taiwan. J. Hazard. Material A73: 209-220.

Mackinnon, Phillips, MPP. 1960. Parliamentary History, Provincial Secretary and Registrar.

Szwillus, Marlisa. 2007. Specific Ingredients/Seafood, Regional \& Ethnic/Japanese, General, Sushi by Marlisa Szwillus, Silverback Books Inc.

Michael W. Allen, Richa Gupta, Arnaud. 2008. The Interactive Effect of Cultural Symbols and Human Values on Taste Evaluation, Journal of Consumer Research, Vol. 35, No.2 (August, 2008), p. 294-308.

Hirsh, Michael. 1991. Cultural Fault Lines Divide Tokyo and Osaka: Japan: The Rivalry between the Country's two major cities is deep rooted and centuries old. And Nowhere is that Rivalry more pronounced than in the Business arena. Associate Press, Oct 3, 1991.

Michel Boko, Antoine Heideveld, Anne Elsen. 1997. Introducing Leaf Packaging in the Netherlands, UNEP-WG-SPD Collaborative Project, December, 1997.

Murdock, George P. 1967. Ethnographic Atlas. The University of Pittsburgh Press.

Newell, Show, and Simpson. 1963. Abstract Theorem Proving, Department of Artificial Intelligence. University of Edinburgh. 
Alchin, Nicholas. 2001. Theory of Knowledge, John Murray Publishers; illustrated Edition.

Nonaka Ikujiro. 1997. Organizational Knowledge Creation, November 11-12, 1997.

O'Shea MA. 2002. Design for Environment in conceptual product design - a decision model to reflect environmental issues of all life-cycle phases. Journal Sust. Product Design, 2: 11-28.

Ormrod, J.E. 1999. Human learning (3rd ed.). Upper Saddle River, NJ: PrenticeHall.

Pajares. 2002. Overview of social cognitive theory and of self-efficacy,12-8-04. From http://www.emory.edu/EDUCATION/mfp/eff.htmlanize

Paul E, Bierly III , Eric H. Kressler, Edward W. Christensen. 2001. Organizational Learning Knowledge and Wisdom. USA: James Madison University Virginia.

Smith, Paul. 1958. How to Do Nothing with Nobody All Alone by Yourself. Tin House Book, Reissue Edition.

Paula Hook, Joe E. Heimlich. 2009. A History of Packaging, Ohio State University Fact Sheet. Community Development.

Freire, Paulo. 1978. Paulo Freire and Revolutionary Pedagogy for Social Justice. San Diego: State University.

Crosby, Philip. 2005. 14 Steps to improvement. McGraw-Hill Adapted with permission DECEMBER 2005.

Prendergast, G., Pitt, L. 1996. Packaging, Marketing, Logistics and the Environment; are there Trads-Offs? Journal of Physical Distribution \& Logistics Management, 26(6), 60-72.

O'Rourke D, Connelly L, and Koshland CP. 1996. Industrial Ecology: a critical review.Int. Jornal Environment and Pollution, 6(2): 98-112.

W.Brislin, Richard. 1976. Comparative Research Methodology. International Journal of Philosophy, Vol.11.

Sakane S. 1986. Japanese Packaging and its Roots in tradition.

Senge, P. et. al. 1994. The Fifth Discipline Field Book: Strategies and Tools for Building a Learning Organization.

Silverman, Phillip: Massinger, Jacquelyn. 1997. The Standard Cross-Cultural Sample. California State Bakerfield: Unpublished Manuscript.

Engstorm, Stephen. 2002. Kant's Distinction between Theoretical and Practical Knowledge. Harvard Review of Psycology, 10(1): 49-63(2002).

Gillebo, Torger. 2010. "Food identity" as a guide in confronting contemporary challenges in food markets and rural districts. Norwegian University of Life Sciences.

E. P., Torrance. 1980. Growing Up Creatively Gifted: The 22-Year Longitudinal Study. The Creative Child and Adult Quarterly, 3, 148-158.

Torres F, Gil P, Puente ST, Pomares J, and Aracil R. 2004. Automatic PC disassembly for Component recovery, Int. J. Manuf. Technol. 23: 39-46.

Tsoukas. 1996. Knowledge Management from Delta, SELASA, 19 October, 1996.

Wang X, Qin Y, Chen M and Wang CT. 2005. End-of-Life vehicle recycling based on Disassembly, J. Cent. South Univ. Technol. 12: 153-156.

Weaver PM, Gabel HL, Bloemhof-Ruwaard JM, and van Wassenhove LN. 1997. Optimizing Environmental product life cycle-a case study of the European pulp and paper Sector, Environ. Resource Econ 9: 199-224.

Yasnitsky, A. 2011. The Vygotsky That We (Do Not) Know: Vygotsky's Main Works and the Chronology of their Composition. PsyAnima, Dubna Psychological Journal, $4(4)$. 